\title{
Moral Imaginative Resistance to Heaven: Why the Problem of Evil is so Intractable
}

\author{
Chris A. Kramer
}

The majority of philosophers of religion, at least since Plantinga's reply to Mackie's logical problem of evil, agree that it is logically possible for an omnibenevolent, omniscient, and omnipotent God to exist who permits some of the evils we see in the actual world. This is conceivable essentially because of the possible world known as heaven. That is, heaven is an imaginable world in a similar way that logically possible scenarios in any fiction are imaginable. However, like some of the imaginable stories in fiction where we are asked to envision an immoral act as a moral one, we resist. I will employ the works of Tamar Gendler on imaginative resistance and Keith Buhler's Virtue Ethics approach to moral imaginative resistance and apply them to the conception of heaven and the problem of evil. While we can imagine God as an omnibenevolent parent permitting evil to allow for morally significant freedom and the rewards in heaven or punishments in hell (both possible worlds), we should not. This paper is not intended to be a refutation of particular theodicies; rather it provides a very general groundwork connecting issues of horrendous suffering and imaginative resistance to heaven as a possible world.

'Imagine that you are creating a fabric of human destiny with the object of making men happy in the end, giving them peace and rest at last, but that it was essential and inevitable to torture to death only one tiny creature ... and to found that edifice on its unavenged tears, would you consent to be the architect on those conditions? Tell me, and tell the truth.' 'No, I wouldn't consent,' said Alyosha softly.'

Fyodor Dostoevsky, The Brothers Karamazov ${ }^{1}$

\section{'Rebellion'}

In The Brothers Karamazov, Fyodor Dostoevsky creates a possible world, a literary fiction that stokes our imaginations about the notion of a realm that promises 'peace and rest at

1 Fyodor Dostoevsky, The Brothers Karamazov, (Trans. Constance Garnett. New York: Barnes and Noble. 1995), p. 226. 
last', or heaven. In the story, Ivan presents this imaginative scenario to his younger brother, and soon-to-be-monk, Aloysha. Ivan accepts the logical possibility of a world in which something like heaven could exist, but the point of his hypothetical question is to illustrate his resistance to such a world. The 'unavenged tears' is a reference to the suffering in this world of an innocent child that he thinks remains unjustified regardless of promises of heaven no matter how perfect we imagine it to be. In this way, Ivan is also rebelling against the very actual world into which he has been thrown.

Even Aloysha, who follows Ivan's visualizations, refuses to go along with imagining that he could have made the world the way that it actually is with the promise of heaven, the ideal state of harmony with God, the very reason we were all created to begin with, ${ }^{2}$ but that requires horrible suffering of innocent children. Aloysha can imagine this possibility, but he would rather not. This can be explained as an instance of moral imaginative resistance against the possible world that includes heaven.

When Ivan details the gruesome treatment of an 8 year old boy (just under the age of moral culpability according to Orthodox teaching) at the hands of a ruthless landowning general, he despairs of finding any meaning in this world, and anticipating a theist's response that heaven is the answer, he despairs of that too: 'Listen! If all must suffer to pay for the eternal harmony, what have the children to do with it? ... And if it is really true that they must share responsibility for all of their fathers' crimes, such a truth is not of this world and is beyond my comprehension ... I most respectfully return Him the ticket. ${ }^{3}$ Here, the mysteries of God's ways lead Ivan to return his ticket to salvation rather than attempt a rationalization that God allows evil for a greater good. To be clear, it is not merely the conception of heaven by itself that Ivan resists imagining; it is the entire state of affairs presumably necessary for anyone to get to heaven. This conception of heaven is consistent with William Lane Craig's, for example:

Heaven may not be a possible world when you take it in isolation by itself. It may be that the only way in which God could actualize a heaven of free creatures all worshiping Him and not falling into sin would be by having, so to speak, this run-up to it, this advance life during which there is a veil of decision-making in which some people choose for God and some people against God. Otherwise you don't know that heaven is an actualizable world. You have no way of knowing that possibility. ${ }^{4}$

So, it is heaven as a final state, the teleological end, along with the necessary conditions in the 'run-up to it' that Ivan resists imagining. But what exactly is involved with imaginative resistance to possible worlds?

\footnotetext{
2 Jerry Walls, Heaven: The Logic of Eternal Joy, (Oxford: Oxford University Press, 2002), p. 64.

${ }^{3}$ Dostoevsky, Brothers Karamazov, pp. 225-6 (my emphasis).

4 William Lane-Craig and Ray Bradley, 'Can a Loving God Send People to Hell? The Craig-Bradley

Debate.' (Online at https://www.reasonablefaith.org/media/debates/can-a-loving-god-sendpeople-to-hell-the-craig-bradley-debate/ 1994), (accessed 2018-10-3).
} 


\section{Imagination and possible worlds}

There are two senses of 'possible' in philosophy: logical and causal. To clarify this, consider two conceptions of 'impossible'. If something is causally impossible, that means that things or state of affairs cannot actually happen in this real world in which we currently reside. It is causally impossible that track star Hussein Bolt can run $85 \mathrm{mph}$. However, it is not logically impossible for him to run that fast. All we need to do is invoke our imaginations in the way any science fiction writer might: create a picture in the 'laboratory of our minds', to borrow from a common phrase used to describe thought experiments. Nothing in this scenario is absurd, contradictory, unimaginable, inconceivable, or logically impossible, even though it is not causally possible for this to happen given the laws of physics and biology in this actual world.On the other hand, try to imagine creating a fiction or possible world in which the central character claims to have gotten a full-body tattoo of herself, only a foot taller. Or try to think of a round triangle, or something existing and not existing at the same time, or a married bachelor. These notions are absurd, inconceivable, conceptually contradictory, and causally and logically impossible. In other words, there is no possible world in which they could exist as they violate laws of logic and philosophers assume that the laws of logic apply to all possible worlds. Theologians and philosophers have constructed a possible world that they claim can be our reality in the future, but it is not possible now with our current fallen and unregenerate state. So, heaven is not an actual world for me right now, but it is a logically possible world for me in the future that I can imagine-if I wish to. But I don't.

\section{Heaven as a fictional but possible world}

Heaven is a possible world because it does not violate any laws of logic. To be a possible world, it must be imaginable. This is a problem if we appeal to some of the scriptures, such as this: 'Eye has not seen, ear has not heard' the contents of heaven, and that heaven far exceeds all that has ever 'entered into the heart of man' as 'we see indistinctly as in a mirror' while on Earth. ${ }^{5}$ More recently, C.S. Lewis follows St. Paul in this: *The thing itself has never actually been embodied in any thought, or image, or emotion'. ${ }^{6}$ It is better than anything you have ever known, so much so you could not possibly have any idea what it will be like. If we interpret these passages and others like them in a literal sense that knowledge of heaven is wholly inscrutable, this will lead to what I call ad hoc mysterianism. ${ }^{7}$

\footnotetext{
5 I Corinthians 2:9, 13:12.

${ }^{6}$ C. S. Lewis, The Problem of Pain (Harper-Collins e-books, 2009), pp. 152-3.

7 'Mysteriansim' typically applies to complex religious notions in a positive sense. For example, a central conception like the Trinity is to be revered but not fully unraveled as if it were a problem. I use the term in a negative sense, coupled with ad hoc, to imply an all-too convenient tactic to sustain the internal coherence of an idea in the face of otherwise compelling counter-evidence against that idea. For instance, when we pray for a sick loved one who soon after is healed, we claim to know it was God and He is good. When we pray and the loved one passes, it is a mystery, it is part of God's plan, it will be revealed to us in the end, as we are far too cognitively limited to comprehend. Ad hoc
} 
Happily, not all theists suggest heaven is wholly ineffable, and a good many have written quite a lot on the subject, so we are able to imagine at least some attributes of this realm and even something about the potential inhabitants. We can borrow from St. Thomas Aquinas, for example, and attempt to grasp the possible world of heaven by analogy, limited though that method might be. We are told that we will be perfected beings able to 'see' the face of God in heaven. Our potential to 'see' God could be analogous to the manner in which we 'see' the solution to a puzzle or 'get' the point of a story.

In the broadest terms, the traditional account of heaven ties together the concepts of salvation and perfect happiness: 'Heaven is the perfect place for people made perfect. Perfection is the goal of God's sanctifying work in us.... He is making us fit to dwell in His presence forever. The utter perfection of heaven is the consummation of our salvation'. We have all used words like 'perfection', but just as we might have all employed the term 'literally', this does not mean we know precisely what we are saying. Yet, even with a terribly vague notion of 'perfection', it is still likely that no one on Earth is presently 'fit' to be in heaven, so heaven is really no more than a possible world or a fiction that we can imagine exists.

In one sense, it begs the question to describe heaven as a fiction, as that too quickly connotes something unreal. Perhaps heaven is and always has been an actual world, and our currently fragmented, finite, and flawed state of mind precludes us from realizing that heavenly mode of existence. Maybe, but the burden of proof to deny such a claim does not rest with me anymore than I should have the burden to prove that I am not currently in the Matrix.

In another sense, it is appropriate to make the analogy between fictional worlds and heaven in much the same way we can look at depictions of the future as a fictional but possible world. Consider the science fiction of someone like Isaac Asimov or Arthur C. Clarke. At the time of their writings, the content of their work was clearly fictional in the sense that it was not actual or even causally possible. But it was logically possible, and in many cases, the scenarios they encouraged readers to imagine are now actual and this fact is likely due to some degree of causal relation between their creative musings and scientists who were able to turn the scientific thought experiments into scientific empirical experiments. A similar case could be made by theists that heaven as a possible world can be made a real state of affairs for me if I believe and do what is required of me in this actual world. To borrow again from Lane-Craig: 'I'm saying that it may not be feasible for God to actualize heaven in isolation from such an antecedent world'. ${ }^{9}$ Further, describing heaven as a fictional world in this way has no more negative connotations than depicting fantasy novelists as creating fictions ${ }^{10}$ that spark our imaginations, encourage moral musings, and

mysterianism is where no conceivable counter evidence actually counts as counter evidence, because we always have at the ready the phrase 'for all we know....'.

8 Walls, Heaven, p. 40, quoting John MacArthur (my italics).

${ }_{9}$ Craig-Bradley Debate.

10 These are imaginative worlds that inevitably import content from the actual world the authors inhabit. See Kendall Walton and Michael Tanner, 'Morals in Fiction and Fictional Morality.' Proceedings of the Aristotelian Society, Supplementary Volumes, Vol. 68 (1994), pp. 27- 66, at pp. 35, 37, and Tamar Gendler, 'Puzzle of Imaginative Resistance' The Journal of Philosophy 97:2 (Feb. 2000), pp. 55-81, at pp. 75-6. 
possibly affect real change in the actual world. This is a view a theist might have toward heaven as a possible world that we hope for in the future. Given how awesome heaven has been traditionally portrayed, it sounds odd to resist imagining it, and yet this is precisely where Ivan and Aloysha, e.g., do so resist. But why? What exactly is moral imaginative resistance to fictional scenarios?

\section{Moral imaginative resistance to fictional or possible worlds}

Consider the following logically possible circumstances within a fictional story: \#1: Giselda occasionally made use of her powers of invisibility to evade capture. \#2: Giselda loved the Romantic period so much that she frequently traveled back to it in her time machine. \#3: 'In killing her baby, Giselda did the right thing; after all, it was a girl'.11 One of these claims stands out. They are all fictional, but while we can say, yes those things are possible in that world, or it is true in that world that these things happen, even though they may not be causally possible in this world, we 'violently resist'12 imagining the third possibility is true even in the fiction, not because we can't, but because we don't want to.

According to Tamar Gendler, it is not that 'Our grasp on moral terms is too tightly connected to their applicability to certain sorts of actions for us to understand what it would be for them to come apart' 13 but that we are reluctant to so separate them: 'And my unwillingness to do so is a function of my not wanting to take a particular perspective on the world - this world - which I do not endorse'.14 Part of what is implied here is that fictional worlds, even the more outlandish sorts, still must have a strong connection to the actual world: 'There is science fiction; why not morality fiction? [because] ... we are less willing to allow that the works' fictional worlds deviate from the real world in moral respects than in nonmoral ones'. ${ }^{15}$

So, if we add a moral dimension to our response, we might say we wish not to imagine that what Giselda did was the right thing in any possible world because we feel it is morally dubious to imagine in this way. ${ }^{16}$ This might not follow if the author or narrator told us that this is the immoral viewpoint of an evil character in the story. But we are not asked to imagine that. Instead, we are asked to imagine that something we take to be

11 Walton and Tanner, Morals in Fiction, p. 37.

12 Gendler, Puzzle of imaginative Resistance, p. 56.

13 Ibid., p. 72.

14 Ibid., p. 74.

${ }^{15}$ Walton and Tanner, Morals in Fiction, pp. 35, 37.

16 Aristotle claimed that it is a mark of an educated person to be able to entertain an idea without believing it. I agree, but I do not think 'entertain' requires of the rational person who is genuinely interested in world-views alien to her own to want those beliefs to be true. I entertain, think about seriously, or consider the reasons Hitler and the Nazis offered for their treatment of non-Aryans. This meets the criteria for Aristotle's 'rational man'. I need not go that further step and imagine that the immorality of their acts of genocide were in fact moral. Doing so is more likely to carry along with it all the emotions and motivations typically coupled with such imaginings. Keith Buhler, expanding on Gendler's account (pp. 80-1), analyzes situations like this with the distinction between imagining and supposing. The latter satisfies Aristotle's condition for a rational person without requiring the adoption of any given worldview (Buhler personal communication). 
immoral--female infanticide--is in fact moral in that possible world. This is what we resist when we engage in moral imaginative resistance in fiction, and we do so in a way not found with non-moral scenarios we know to be false.

We know that it is not true that a human can run $85 \mathrm{mph}$, but we do not resist imagining it--indeed such possibilities make it into movies all the time. On the contrary, we might know that it is not true that murdering an infant is the moral thing to do, but in this case, we do resist imagining that it is morally just in any possible world, even as a fiction. Imaginative resistance drops if we are informed, directly or indirectly, that the author intends for audiences to confront the moral ambiguities and complexities of the fictional characters, for example. But we resist imagining along with the author when it is clear they are coaxing us to make-believe that an immoral act is moral in their fictional construction. ${ }^{17}$

However, one might respond that imagining Giselda did the right thing is not only possible but also desirable for some people, and that we cannot make universal claims about what should and should not be imagined even (especially) in fictional worlds. In response, I presuppose a brand of moral realism. This is the view that there are moral truths in the world independent of any culture or individual or time period, and, not surprisingly, this is the position of most theists. I assume a version of the Divine Command theory that grounds moral reality in the known will of God: think of the Ten Commandments and Natural Law theories. ${ }^{18}$ We would be hard-pressed to find a Divine Command theorist who would not resist imagining that infanticide is a moral good in any possible world. To do so would be to imagine that which you know to be immoral as moral. For many people like Ivan this is the very reason they resist imagining a possible world like heaven can render this world meaningful and just. They are asked to imagine an upside-down morality that they resist no matter what its source, as David Hume informs us: 'And where a man is confident of the rectitude of that moral standard, by which he judges, he is justly jealous of it, and will not pervert the sentiments of his heart for a moment, in complaisance to any writer whatsoever'. ${ }^{19}$ This complicates things for those of us who take God as the 'author' or source of heaven, because, via Divine Command theory, He is also the source of our morality. He is viewed as our omni-benevolent parent who promises salvation, clearly delineating what is right and wrong, proclaiming to love us all as His children. Yet for most, He remains hidden or wholly absent from beginning to end even when we experience horrible evils, and His palpable absence during these times increases our suffering.

\footnotetext{
${ }_{17}$ One thing that this might show is that we tend to take moral truths to be more stable across possible worlds than causal or physical facts. The laws of physics across possible worlds seem malleable in our imaginations in a way laws of morality, so to speak, do not.

18 Aquinas, 'Ethics and Natural Law', in The Philosophy of Religion $5^{\text {th }}$ Edition, edited by Michael Peterson, William Hasker, Bruce Reichenbach, David Basinger. (New York: Oxford University Press, 2014), pp. 638-640, at p. 639.

${ }^{19}$ David Hume, 'Of the Standard of Taste', in Essays: Moral, Political, and Literary, edited by T.H. Green and T.H. Grose. (London, 1882) at p. 283.
} 


\section{Why resist imagining heaven: the problem(s) of evil}

It is common to invoke the prospects of heaven as a response to the problem of evil or what appears to be unnecessary suffering of innocent humans. Here is a summary of one version of the problem of evil: If God is all good (omnibenevolent), all powerful (omnipotent), and all knowing (omniscient), it would be unlikely that evils or unnecessary suffering would exist. This is because any potential evil that might happen, God would know about it, be able to stop it, and would want to do so. But, there is a great deal of evil, from genocide to the Zika virus, from earthquakes to Ebola, to all of the moral evils humans perpetrate against innocent children recorded by Ivan in The Brothers Karamazov. On one side of the issue, heaven is an answer to the problem of evil; on the other, the problem of evil makes the prospects of heaven untenable. It is difficult to argue that horrible things don't happen to good people, and perhaps even more difficult to claim that it is ultimately good that such things happen..$^{20}$ On the traditional account God is aware, able, and willing to stop evil, but permits it for some greater good that necessarily could not have come about if such evil did not occur. This scenario is not only logically possible, it is elemental in many free will replies to the problem of evil from St. Augustine in the $4^{\text {th }}$ Century CE to Alvin Plantinga today, and central to realizing the potential state in heaven.

Consider why heaven necessitates suffering given these options: 1. A lot (or just some) horrendous suffering of innocents is unnecessary as it serves no greater purpose, either in bringing about a greater good or precluding a greater evil from happening; 2 . All suffering is necessary to bring about a greater good or preclude a greater evil from happening. Option 1 is abhorrent to just about everyone, so we are left with 2 . But in order to avoid the first horn, which is not at all easy to dismiss, we have to imagine God is something like a utilitarian who is constrained by particular means to achieve a desired end. That end or goal has to be great enough to justify the means. Or as Jerry Walls frames it:

\footnotetext{
Our only real hope is that the past might be redeemed....the doctrine of heaven represents the only substantive hope that the past might be redeemed in such a way that we can be fully glad for our existence even if our existence is somehow implicated in the worst tragedies of human history. ${ }^{21}$
}

For Ivan, this putative redemption comes at too great a cost to imagine that it is actually just even if the designer of it all has no choice but to allow children to suffer - those for whom the need of redemption seems particularly peculiar.

One form of this argument claims that even God cannot intervene in this world to halt evil or force us to seek Him in heaven, for to do so would limit morally significant freedom, and the loss of this would be worse than if there was no suffering at all. The

20 But there is no shortage of such arguments: see Walls Heaven, Lewis, Problem of Pain, Alvin Plantinga 'The Free Will Defense', in The Philosophy of Religion $5^{\text {th }}$ Edition, edited by Michael Peterson, William Hasker, Bruce Reichenbach, David Basinger, (New York: Oxford University Press, 2014), pp. 338-356, and John Hick, Evil and the God of Love, (New York: Harper and Row, 1978), for a small sample.

21 Walls, Heaven, p. 130. 
connection to heaven is clear: if you have freely chosen good or evil, then you either earn the rewards of heaven or you don't. Free will and the inevitable poor choices by many is still essential on more nuanced accounts of heaven, such as John Hick's or Jerry Walls', and some readings of scriptures where heaven is the state of perfect or beatific connection with God that goes beyond mere punishment and reward. In order for this to be possible, we have to mature spiritually, and a necessary component to the growth required to make us 'fit' to be in a relationship with God is our freely choosing to seek Him - or not.

In the opening quotation, Ivan assumes that suffering is 'essential and inevitable', something implied with the traditional Christian conception of heaven and at times stated outright: '...the existence of creatures with free choice that are highly vulnerable to each other and their environment will inevitably result in various sorts of evil'.22 But, for those who transform themselves sufficiently to be capable of experiencing heaven, the suffering on Earth will finally be understood as necessary, but infinitesimally minute in comparison to the eternal joys of heaven. Why can't we all see this? How could there be moral imaginative resistance to this positive account of heaven?

There is a common saying, not conveying the same sense that Ivan uses it (quoted above), that Jesus is 'Not Of This World' (NOTW). This is meant to be helpful for us while still on Earth by encouraging a wider perspective: we are 'in' this world but not 'of' it. ${ }^{23}$ Aloysha tries hard to sustain this outlook responding to Ivan that he has forgotten that the tears of the tiny creatures are not unavenged, rather 'on Him [Jesus] is built the edifice, and it is to Him they cry aloud: 'Thou art just, O lord, for Thy ways are revealed!' 24 To which of God's children are these ways revealed and how and why to them in particular? Answers to these will go a long way toward addressing what role the possible world of heaven might play in making sense of, and justifying, the tribulations of this world.

\section{The parent analogy}

God's constant intervention to prevent my potential suffering, or to stop me from harming someone else, or to force me to love Him, would be akin to a divine helicopter parent who stunts the growth of her child by denying that child the opportunity to fail, and then learn from that failure, or to suffer, and learn from that suffering, or to freely develop a character requisite for properly loving that parent. I do not dispute the general idea behind these assertions, except for the last one, which I will address later. Indeed, I often fear that I involve myself too much already in the lives of my small children, potentially curbing the cultivation of their character or souls, to borrow from John Hick. ${ }^{25}$

The parent analogy in response to the problem of evil and anticipation of heaven is not new. Here is a contemporary account: 'Just as we expect a small child to be blind to the reasons an adult has for allowing her to suffer justified pain, so we should expect that

22 Robin Collins, 'The Anthropic Teleological Argument', in The Philosophy of Religion 5th Edition, edited by Michael Peterson, William Hasker, Bruce Reichenbach, David Basinger. (New York: Oxford University Press, 2014), pp. 187-196, at p. 192, my italics.

23 John 17:14-15.

24 Dostoevsky, Brothers Karamazov, p. 227.

${ }^{25}$ Hick, Evil and the God of Love, pp. 253-261. 
we will be blind to the reasons God has for allowing our justified suffering' 26 When I allow the physician to stick a needle in my child because this is the right thing to do from my perspective, my son still cries in a way that implies I have let him down. Put in terms of the traditional problem of evil, I am aware of the suffering that is coming and I know how it could be stopped, I have the power to step in and stop that suffering, and, as a good parent, I would want to stop it. 'Why don't I stop it?', Milo might ask.

Of course, being fairly certain of the consequences, I recognize that a greater evil would result if I tackled the doctor and stopped the suffering in that moment; my child might develop measles, mumps and/or rubella, notwithstanding my apparent heroism. Also, I intend to raise my children so they eventually become emotionally and intellectually developed people, capable of interacting with and learning from others. Given the way the actual world is, such maturity cannot be nurtured in an environment hermetically sealed to stave off any and all discomfort or error. ${ }^{27}$ Even if this type of overbearing parenting were possible, the negative consequences of arrested development would outweigh the positives of no suffering and few errors. In other words, my allowing the temporary and minimal suffering of my child is justified.

But do we have good reason to imagine that heaven can provide analogous justification for the horrendous suffering of even one of God's children? Do we accept St. Paul's insistence that our childlike ignorance now will give way to a grown-up knowledge in the future: 'For we know in part and we prophesy in part; but when the perfect comes, the partial will be done away. When I was a child, I used to speak like a child, think like a child, reason like a child; when I became a man, I did away with childish things." 28 Much of this depends upon a few interrelated questions: 1 . What does it mean to 'reason like a child' and if current adults are like children in this analogy, what are actual children supposed to be? 2. Can adults in this life ever actually reason properly so as to 'see' the justice in God's hiddenness and His allowing not just suffering, but torture of the worst sorts? 3. Does someone like Saul achieve maturity in thinking on his own or was it foisted upon him directly by his now-revealed Father through the conversion experience? 4. Related to 3, is God's intervention on behalf of people like Saul arbitrary and capricious?

By 'child' I follow Ivan's lead and presume an age below the level of moral reasoning and culpability, admitting that this can be a rather vague point. Anyone under the age of 5 surely does not have the sufficient capacity to truly know right from wrong and does not possess the obligatory freedom to choose between them. This is what I mean with respect to 'reasoning like a child', perhaps a bit different than St. Paul who seems to imply a kind of self-centeredness, immaturity, and naiveté. I will focus primarily on 1-2.

26 Trent Dougherty, 'Skeptical Theism', The Stanford Encyclopedia of Philosophy (Spring 2014 Edition), edited by Edward N. Zalta. Online at: http:// plato.stanford.edu/archives/spr2014/entries/skeptical-theism/ (accessed 2015-05-15), at p. 19, quoting Stephen Wykstra.

27 See Hick, Evil and the God of Love, pp. 292-309 and Lewis, Problem of Pain, pp. 86-110.

28 I Corinthians 13:9-12. 


\section{Moral imaginative resistance to heaven}

As appealing as the parent analogy sounds at first reading, it is another instance of ad hoc mysterianism, and when it is fully unpacked, it has the opposite effect as that intended by its authors: rather than explaining the suffering of this world, justifying it by the eventual fruits in heaven that we, like children, fail to comprehend now, it elicits moral imaginative resistance. This is because the mystery of the Lord's 'ways' which allow the suffering of children is not at all analogous to cases of parents justifiably allowing their own children to suffer briefly for a greater good or avoiding a worse evil; a necessary trade off at times in a world they did not create but have to live in.

Following Ivan, to see why God allows the world to be the way it actually is in order to make heaven a possibility for us requires thinking that is not of this world, and it does not help to be told to just wait until the end for whatever partial understanding we now have to be made full. Yes, we say things like this to our children, but we typically mean 'Wait until you are a bit older when you will be able to understand', because when we are actual children, we simply cannot reason in a way that would make sense of our earthly torments. The parent analogy tries to have it both ways: we are childlike and ignorant about God's ways, but still knowledgeable enough to warrant our suffering here and now, and punishments or rewards in the afterlife.

What are we supposed to imagine about actual children in this life in relation to God, and in what way does He soothe them during their suffering? A benevolent parent does all she can to inform her child why some suffering is necessary; she tries to mitigate that suffering as much as she can by being there for her child especially if she knows this child could not possibly comprehend the situation. She makes her best effort to reveal the difference between right and wrong, and acts as a model for moral behavior so that eventually the child can cultivate similar moral sensibilities. The expected ad hoc reply: 'For all we know, God does all of this for the suffering children, and they get an immediate ticket straight to heaven'. But if so many adults consistently fail to even feel the presence of the benevolent parent during unbearable travails, it is even harder to imagine that God is there for children.

It does no good to claim that moral sensibilities only apply to human parents, as the very point of employing the parent analogy in the first place presupposes that God would act like a beneficent parent, but His absence in the lives of so many of His children in times of need is inconsistent with a conception of good parenting in any possible world even if we somehow 'know' that the goods of heaven outweigh the perils of this life.

Related to point 2 above, grown-up humans are like children to God in the parent analogy, but our 'adulthood' in relation to God seems forever out of our reach in this world. Because of this, we should not deserve praise and rewards in heaven, and surely not eternal hell, if everything is to be decided in the here-and-now. We simply do not understand the ways of God for we continue to 'reason like a child', which is to say we don't really know right from wrong any more than a child would. This seems to follow so long as we imagine-without resistance-that God's allowing child suffering is just. Imagining in this way, we bracket our normal moral reasoning that would charge any other parent with neglect. We suspend this form of reasoning, as St. Paul suggests, because to rely upon it would be as effective as founding our epistemic certainty of Santa's existence, e.g., on the arguments employed by a child. We are instructed to 'put away' such thinking. 
The parent analogy requires that adults are only ever like children in this world who cannot comprehend the ways of God, and that it is only after this life is over that we gain the requisite knowledge; unless one has a direct revelation of some sort from the divine parent who, on all rational accounts, appears to be playing favorites. But if we do understand right from wrong, and God's moral commands are clear enough, then, paradoxically, we should resist imagining that heaven justifies allowing child torture and the like.

It is not our feebleness of mind on this earthly plane of existence that precludes us from imagining a morality that is NOTW. It is the desire deep within us to not want to remove ourselves from this-world morality; morality that we do understand, according to theists, because it is derived from divine commands or our natural, innate moral conscience. ${ }^{29}$ This resistance 'is a function of my not wanting to take a particular perspective on the world-this world-which I do not endorse' ${ }^{30}$ We rightly resist imagining, if and when we do, the utilitarian thinking that heaven is the ends brought about by the means of allowing the torture of children. Heaven remains an otherworldly possibility that requires us to imagine that something that we know to be immoral is moral.

Those who resist imagining that the injustice of divine neglect is actually just, given the possible world of heaven, do so for the same reasons they resist imagining that the extreme negligence of a human parent in the real world or in a fiction is in fact a moral good. The inkling of this is found with some theists:

Why do we think that we ought to encounter God? Simple: Our concept of God is the concept of a perfectly rational, perfectly wise being who loves us like a perfect parent.... We all know that...it is bad for a child to grow up without a father or a mother, or to believe - for good reasons or bad - that her father or mother doesn't love her. ${ }^{31}$

I agree. The very reason the parent analogy is so compelling for theists-it connects us directly and personally with God-is the same reason it elicits moral imaginative resistance when we are told God permits horrible evils on particular children from whom God remains hidden.

To make the analogy more apt, imagine a parent who only indirectly reveals herself to her own child, hiding from her from the very start, only ever offering hints of her existence and even going so far as to purposely distance herself from the child with the intention of cultivating within that child the desire and need for that hidden parent. ${ }^{32}$ Further, this parent has many children, but reveals her love openly and unmistakably only to a couple of them. To these, she occasionally directly intervenes in their lives to reassure them about the meaning of suffering in this life and the treasures in the afterlife ${ }^{33}$ or even steps in to stop them from great harm or from making a horribly evil choice (Saul).

${ }^{29}$ Aquinas, Ethics and Natural Law, pp. 639-40.

30 Gendler, Puzzle of imaginative Resistance, p. 74.

31 Michael Rea, 'Divine Hiddenness, Divine Silence', in The Philosophy of Religion: An Anthology, 6 ${ }^{\text {th }}$ Edition, edited by Louis Pojman and Michael Rea, (Australia: Wadsworth, 2012), pp. 266-275, at p. 268.

32 This is a point Hick makes, Evil and the God of Love, pp. 281-89.

33 See James, Varieties, pp. 410-12 on St. Theresa of Jesus. 
She also makes it clear that the ends could not be achieved without reality being this way, and this apparently is sufficient justification for those individuals, but not enough for the other children to accept without having any direct illumination or epistemic justification of their own. ${ }^{34}$ For the vast majority of her other children, she refrains from intervening in any perceptible way on their behalf, allowing some to harm other innocent children and others to suffer terrible pain and mental anguish with the presumption that she does not even exist.

This is bad enough, but it is not much better even in cases of suffering in which we might 'know' the outcome will be a greater good. It is hard to imagine what benefit could come from allowing a child to be tortured, but as a tentative stab, consider that the parent had good reason to believe, at least as good of a reason as any theist has for the likelihood of an afterlife and that the child in question will go to heaven, that were the child not to be horribly abused for years she would not have developed the strong moral character needed to help other torture victims.

But we want the torture victim to benefit too because presumably the child is not consciously sacrificing herself for the greater good, so we can also imagine that in her later life she ends up flourishing somehow as a result of the years-long torture. Even if everything above is true and she is in fact better off for it in the future, I resist imagining it. The problem of evil is incalculably worse. The torture of innocents throughout history, either by people or nature, is impossible to estimate. ${ }^{35}$ If we resist imagining that the individual parent case is an instance of justice in the end, we should have even more reason to resist imagining that heaven justifies suffering in this world.

While this account sounds like a caricature, it matches surprisingly well many of the descriptions of God as a parent who apparently has 'epistemic favorites.' Those are the children for whom He has adequately revealed Himself and the truth about heaven and earth, in some cases so manifestly that the recipients of these revelations are certain enough to die or kill for their beliefs. The rest of His children just have to take the favorite's word for it. In fact, St. Paul, formerly known as 'Saul' who persecuted Christians, clearly not at that time fit to be in a relationship with God in heaven, stands as an exemplar of the omnibenevolent parent's ostensible arbitrariness and capriciousness. The burden is on the theist to demonstrate at least some reason why Saul needed to have his mind and heart changed in a way other potentially destructive humans did not. History is rife with people who have performed hideous acts that harmed multitudes of innocent people. Maybe God did reveal Himself in a similar manner to all of those people as He did for Saul, and they

${ }^{34}$ Ibid., pp. 422-3, on the 'authoritative' of these experiences only for the experiencer.

35 But for a scientific account of the sheer numbers of innocent children who have suffered in this world, see Gregory Paul, 'Theodicy's Problem: A Statistical Look at the Holocaust of the Children, and the Implications of Natural Evil for the Free Will and Best of all Possible Worlds Hypotheses', Philosophy \& Theology 19:1-2 (2011), pp. 125-149. No matter what the consequences, allowing for torture even of those whom we know are guilty of acts of terrorism, e.g., and might have information to divulge, is still considered wrong, at least according to many theists who use their religious conscience to ground their moral conscience. Put another way, we do not want to imagine a world in which allowing torture and the like is just. A quick Google search provides a multitude of Christian sites that rail against torture. For just one, see: http://www.christianitytoday.com/ct/2006/february/23.32.html (accessed 2015-5-28). The title of the document is ' 5 Reasons Torture is Always Wrong.' 
freely chose to ignore Him. But theists need to support that view, and appealing to ad hoc mysterianism will not help.

God may have His reasons for intervening in these ways for some, even providing the necessary push to make them 'fit' to be in a relationship with Him in heaven, but our very God-given moral sensibilities should compel us to resist imagining that this mode of 'parenting' is morally acceptable. This is revealed most powerfully given God's hiddenness from most people.

According to Michael Rea, 'God wants us to be seekers after him, and what better way to cultivate that disposition than to hide?'36 Yes, as long as this game of hide-and-seek does not last for the entirety of one's earthly life, as it clearly seems to for most of the world's population who are not Christians, and frankly, it is the case for many avowed Christians as well. Walls admits as much but invokes the ad hoc intermediate, and theologically controversial, realm known as purgatory to deal with these otherwise immoral situations that neither allow for enough time on earth to mature, nor offer sufficient individual freedom to control the situations one is often thrown into: 'More specifically, it seems morally intolerable that chance should have a role at all in something of such extreme importance as one's eternal salvation' ${ }^{\prime 7}$ But that just is the problem with this brief and difficult life on earth.

There is not enough time, freedom, or evidence on earth to properly prepare us for a heavenly relationship with a God who seems to purposely hide from us in times of the greatest suffering. It does not help that many of His children are born into families who might have no inclination toward any religious conceptions of heaven or that one should seek salvation and peace and rest at last. Moral luck plays far too great a role in situating us in this world in relation to the possibility of the next. We know there is disagreement about heaven and God's revelations (or lack) among adults, including many brilliant, wellintentioned non-theists, ${ }^{38}$ but keeping with the parent analogy, actual children have even less time, less capacity, and less freedom to believe and act appropriately to render God's absence in their lives as anything but extreme negligence.

In response, Rea considers the possibility that God remains hidden ('silent') for His own reasons. Just as we might improperly respond to the silence of another human, perhaps we are doing the same with God: 'sometimes our being pained by another person's behavior is our problem rather than theirs-due to our own dysfunctional attitudes and ways of relating to others, our own epistemic and moral vices, our own immaturity and the like'. ${ }^{39}$ We are back to the need for character and soul-building to prepare us for heaven.

But Rea at once compares our relationship to God with that of other humans, and then tells us 'God is alien and 'wholly other' from us as it is possible for another person to

\footnotetext{
${ }^{36}$ Rea, Divine Hiddenness, p.

37 Walls, Heaven, p. 68.

38 Walls spends the majority of his work poking holes in other theists' interpretations of scripture and analogies regarding heaven. These are all well informed individuals about the scriptures and the history of commentaries on heaven, hell, and evil; they are adults who have put away childish things, many very smart fathers of the church. Why are so many brilliant thinkers so wrong on these supremely important matters?

39 Rea, Divine Hiddenness, p. 273.
} 
be $^{\prime} .{ }^{40}$ When one feels pained by the unmistakable absence of God during times of crisis, doubt, and atrocity, Rea muses that perhaps it is the one who doubts who is at fault. Maybe those whose children have been tortured and killed in holocausts or hurricanes, and who have yet to receive a single unambiguous message from their divine parent as to the justification of it all in heaven, are inappropriately refusing 'to accept God for who God is'. ${ }^{41}$ But we have just been informed that God is 'wholly other' and alien to us. Making us culpable for failing to believe in the promises of such a parent is blaming the victim on a biblical scale.

Beyond that, the story about the redemptive world of heaven ignores the suffering of children who truly do not have the capacity to understand when they may or may not be responding appropriately to their divine parent. Again, if adults are akin to children in relation to God, what are actual children in relation to God? Aloysha's words are telling: 'Thou art just, $\mathrm{O}$ lord, for Thy ways are revealed!' 42 The arbitrary intervention and clear cases of intentional distancing from the lives of His children are supposed to be imagined as moral given the possibility of heaven. We are to suspend our clear moral reasoning that is of this world. But, as cases of moral imaginative resistance in fiction show, such moral views are in an important way more stable across 'all possible worlds' than the laws of physics. ${ }^{43}$ We rightly resist imagining that extraordinary parental neglect is morally acceptable. When God remains hidden from His children who cannot possibly understand why, we should rightly resist imagining that such non-intervention is morally just. Failure to do so seems to turn the famous phrase attributed to Dostoevsky on its head, from 'If there is no God, everything is permitted', to the ad hoc 'If there is a God, everything is permitted'.

\section{Conclusion}

I am not presenting a case for moral imaginative resistance against the justification of gratuitous evils, although that would follow from this argument. ${ }^{44}$ This is a case for moral imaginative resistance against the possible world in which the inevitability of children suffering is portrayed as a just world. Since an all-good God cannot remove the suffering of children in this world without precluding free will and a beatific relation in heaven, it must be the case that the suffering is necessary, and thus, we are told to imagine, it has to be just. We can imagine that the 8-year-old boy in Dostoevsky's story upon whom such horrible evils were perpetrated, is in heaven with God, and even that he is happy in 'peace and rest at last'. But I am unconvinced that this provides a 'wider context that alters our view of it in such a way that we change the significance of that evil' ${ }^{45}$ What we are in fact

\footnotetext{
40 Ibid., p. 272.

41 Ibid., p. 274.

42 Dostoevsky, Brothers Karamazov, p. 227.

43 Gendler, Puzzle of imaginative Resistance, p. 78.

44 See Trent Doughtery, 'Reflections on the Deep Connection Between Problems of Evil and Problems of Divine Hiddenness', European Journal for Philosophy of Religion 8:4 (Winter 2016), pp. 65-84, at p. 74 'God and unjustified evil are non-compassable, they never occupy the same logical space'.

45 Walls, Heaven, p 123.
} 
asked to do is minimize the actual suffering in contrast to the hopes for a greater good in the end. This is what St. Paul insists in Romans 8: 'the sufferings of this present time are not worth comparing with the glory that is to be revealed to us'. He might be able to speak for himself, or even some of the adult followers of Christ in this utilitarian fashion, but not to the children or their parents who have had no such revelation to offer the necessary hope. Even with such hope the idea of redemption in heaven for children horribly harmed on earth is difficult to imagine on moral grounds.

The parent analogy asks us to imagine that what we take to be immoral, a parent who permits awful harms to his children, who then blames them for failing to properly believe in him and trust him, is moral. The escape clause 'God works in mysterious ways' is an ad hoc dodge. To borrow the words of Clark Pinnock, but in a very different context: 'such things do not deserve to be called mysteries when that is just a euphemism for nonsense' ${ }^{46}$ Constructing in our imaginations the possible world known as heaven does not alleviate our concerns.

Any author can get us to imagine horrific child-abuse and neglect, but not that such things are morally acceptable even in a fictional or possible world. Of course theists do not think that suffering is good (some think it can be a virtue) or that genocide is good. But they do assume we will imagine along with them that God allowing it is just-and this I will not. It is to accept that the worst imaginable atrocities are in fact part of a just plan that we simply fail to see because we are like children. If we are truly incapable of distinguishing between examples of appalling neglect through purposeful absence and arbitrary intervention, and examples of loving care, then we have little capacity to make any moral claims. But this is absurd. To go along with imagining that the allowance of such suffering of children is ultimately just is truly thinking that is not of this world, and so I resist.

Through the employment of parent analogies, possible worlds, and potential future states of affairs, the theist is invoking imaginative scenarios to convince us that what we take to be unjust is in fact ultimately part of a just plan. We must rationalize away in a case of special pleading or fallacious appeal to ignorance what would otherwise be an inconsistent application of our moral imagination. Faith in the goodness of God overrides our justified trust in our moral sense when we are asked to imagine, and we do so without resistance, a possible world in which it is just that a divine parent allows her children to be tortured for any reason. To borrow again from Hume: 'I cannot, nor is it proper that I should, enter into such [vicious] sentiments'. ${ }^{4748}$

Chris A. Kramer, Santa Barbara City College cakramer1@pipeline.sbcc.edu

46 Clark Pinnock, 'The Openness of God-Systematic Theology,' in The Philosophy of Religion: An Anthology, $6^{\text {th }}$ Edition, edited by Louis Pojman and Michael Rea, (Australia: Wadsworth, 2012), pp. 22-36, at p. 29.

47 Hume, Standard of Taste, p. 247.

48 I would like to thank the anonymous reviewers and especially my colleagues and friends Michelle Rotert and Brian Wagner for all of their insightful conversations about this issue and many others. 


\section{Bibliography}

Aquinas, Thomas. 'Ethics and Natural Law'. In The Philosophy of Religion $5^{\text {th }}$ Edition, edited by Michael Peterson, William Hasker, Bruce Reichenbach, David Basinger. New York: Oxford university Press, 2014, pp. 638-640.

Buhler, Keith. I Wouldn't Imagine That if I Were You--Virtue Ethics and Moral Imaginative Resistance to Images. Online at https://uky.academia.edu/KeithBuhler, (accessed 201604-10).

Collins, Robin. 'The Anthropic Teleological Argument'. In The Philosophy of Religion $5^{\text {th }}$ Edition, edited by Michael Peterson, William Hasker, Bruce Reichenbach, David Basinger. New York: Oxford University Press, 2014, pp. 187-196.

Dougherty, Trent. 'Reflections on the Deep Connection Between Problems of Evil and Problems of Divine Hiddenness', European Journal for Philosophy of Religion 8:4 (Winter 2016), pp. 65-84.

Dougherty, Trent. 'Skeptical Theism', The Stanford Encyclopedia of Philosophy (Spring 2014 Edition), edited by Edward N. Zalta. Online at http://plato.stanford.edu/archives/spr2014/entries/skeptical-theism/ (accessed 2015-05-15).

Dostoevsky, Fyodor. The Brothers Karamazov, translated by Constance Garnett. New York: Barnes and Noble, 1995 (1879).

Gendler, Tamar. 'The Puzzle of Imaginative Resistance', The Journal of Philosophy 97:2 (Feb. 2000), pp. 55-81.

Hick, John. Evil and the God of Love, New York: Harper and Row, 1978.

Hume, David. 'Of the Standard of Taste', in Essays: Moral, Political, and Literary, edited by T.H. Green and T.H. Grose. London, 1882.

James, William. The Varieties of Religious Experience, edited by Martin E. Marty. New York: Penguin Classics, 1985 (1902).

Lane-Craig, William, Bradley, Ray. 'Can a Loving God Send People to Hell? The CraigBradley Debate.' Online at https://www.reasonablefaith.org/media/debates/can-aloving-god-send-people-to-hell-the-craig-bradley-debate/ (1994) (accessed 201810-3).

Lewis, C. S. The Problem of Pain. Harper-Collins e-books, 2009.

New American Bible: St. Joseph Medium Size Edition. New York: Catholic Book Publishing Company, 1991.

Paul, Gregory. 'Theodicy's Problem: A Statistical Look at the Holocaust of the Children, and the Implications of Natural Evil for the Free Will and Best of all Possible Worlds Hypotheses.', Philosophy \& Theology 19:1-2 (2011), pp. 125-149.

Pinnock, Clark. 'The Openness of God-Systematic Theology', in The Philosophy of Religion: An Anthology, $6^{\text {th }}$ Edition, edited by Louis Pojman and Michael Rea. Australia: Wadsworth, 2012, pp. 22-36.

Plantinga, Alvin. 'The Free Will Defense', In The Philosophy of Religion $5^{\text {th }}$ Edition, edited by Michael Peterson, William Hasker, Bruce Reichenbach, David Basinger. New York: Oxford University Press, 2014, pp. 338-356.

Rea, Michael. 'Divine Hiddenness, Divine Silence', in The Philosophy of Religion: An Anthology, $6^{\text {th }}$ Edition, edited by Louis Pojman and Michael Rea. Australia: Wadsworth, 2012, pp. 266-275. 
De Ethica. A Journal of Philosophical, Theological and Applied Ethics Vol. 5:1 (2018)

Swinburne, Richard. 'A Theodicy of Heaven and Hell', in The Existence and Nature of God, edited by Alfred J. Freddoso, Notre Dame Press, 1983, pp. 37-54.

Walls, Jerry. Heaven: The Logic of Eternal Joy. Oxford: Oxford University Press, 2002.

Walton, Kendall, and Tanner, Michael. 'Morals in Fiction and Fictional Morality', Proceedings of the Aristotelian Society, Supplementary Volumes, Vol. 68 (1994), pp. 27- 66. 